\title{
Los productos limpios y los orgánicos
}

Ing. Agro. Gonzalo Carabajo

uando hablamos sobre la alimentación con productos provenientes del cultivo del campo, las preguntas van hacia: ¿Cómo adquirir productos o alimentos no contaminados, productos limpios o simplemente productos ecológicos u orgánicos?

Entonces cabe hacer hincapié sobre la diferencia entre estos tres conceptos que no son sinónimos.

Para comenzar la lista de productos contaminados podemos citar a aquellos huertos cultivados a las orillas de las cerreteras o caminos carrozables que reciben el monóxidos de carbono cuyos residuos como el plomo se impregna en el follaje de las plantas; el uso del agua que proviene de ríos y canales abiertos y expuestos al manipuleo de los habitantes en sus orillas; el manejo de los productos desde la siembre y todo el proceso de la cosecha sin ninguna norma de higiene.

Por productos limpios entendemos a aquellos provenientes de un manejo mixto, como es el uso moderado de productos químicos que se alternan con el uso de productos orgánicos, para el control de plagas y enfermedades, y que para su cosecha se cumplen los 7 o 10 días desde su última aplicación.

Los productos ecológicos u orgánicos son aquellos que cumplen las normas de producción que excluye en su totalidad el uso de fertilizantes, pesticidas, reguladores de crecimiento y más aditivos químicos para las plantas, acercándose en lo posible a los procesos que se desarrollan espontáneamente en la naturaleza. En cambio promueve el uso adecuado de los recursos: tierra, agua, abonos orgánicos, plantas nativas, plantas repelentes, siembra en asociación, rotación, uso de insectos benéficos, parasitoides, predatores, antagónicos, etc. Aplicación de plaguicidas de origen botánico como también el uso de elementos puros como la cal agrícola, azufre, y más oligoelementos que permiten mantener la actividad biológica del suelo.

Todos los que estamos vinculados con el agro en el manejo y la producción, somos los responsables directos de ofrecer una alimentación sana, limpia y garantizada de nuestra familia y de la sociedad.

Para obtener alimentos sanos y confiables optimicemos los secretos de la madre naturaleza y no atentemos contra ella en forma egoísta, creyendo que es únicamente nuestra; pensemos en las generaciones venideras, teniendo siempre en mente lo expresado por el Ing. Peter Crosh: "La tierra que utilizamos hoy, la estamos alquilando a nuestros nietos"

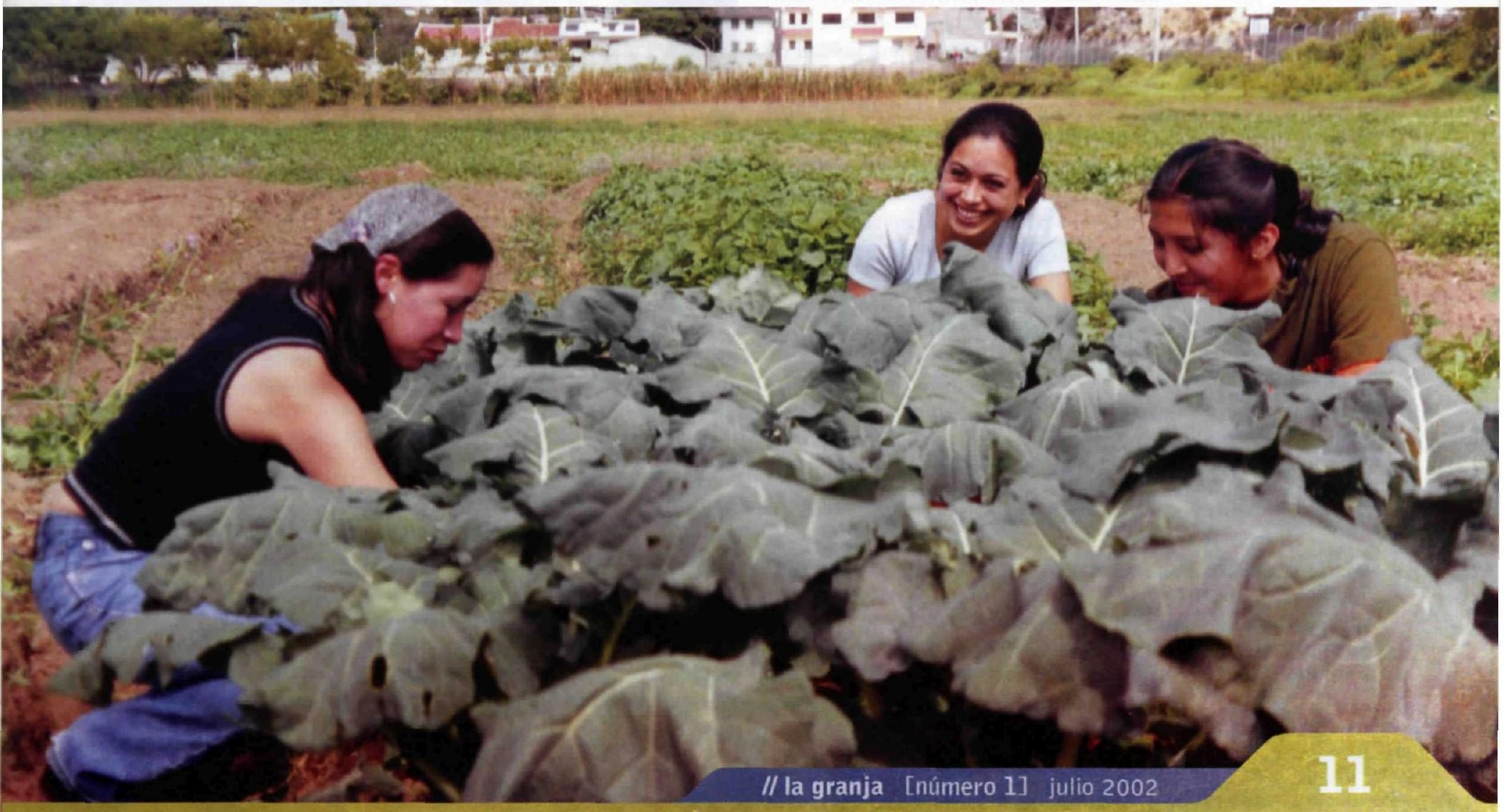

